\title{
Settlement of shore crab Carcinus maenas on a mesotidal open habitat as a function of transport mechanisms
}

\author{
Luis Giménez ${ }^{1,2, *}$, Stephan Dick ${ }^{3}$
}

\begin{abstract}
${ }^{1}$ Biologische Anstalt Helgoland, Foundation Alfred Wegener Institute for Polar and Marine Research, 27498 Helgoland, Germany ${ }^{2}$ Sección Oceanología, Facultad de Ciencias, Iguá 4225, 11400 Montevideo, Uruguay
\end{abstract}

${ }^{3}$ Bundesamt für Seeschifffahrt und Hydrographie, Bernhard-Nocht-Straße 78, 20359 Hamburg, Germany

\begin{abstract}
We evaluated the patterns of larval settlement of Carcinus maenas on natural substratum and its relationships with forcing factors related to larval transport mechanisms. Settlement was estimated as colonisation of traps containing defaunated substratum. Traps were deployed at low tide for 24 to $26 \mathrm{~h}$, in the intertidal of the island of Helgoland (North Sea, German Bight), every day during the settlement seasons of 2003 to 2005. The forcing factors were wind direction, predicted residual surface (0 to $8 \mathrm{~m}$ ) currents, and days since spring tide. The settlement season lasted from the end of June to the end of August; colonisation rates varied among and within years, without a clear pattern. In 2003 and 2004, long periods of low colonisation rates occurred in association with strong and persistent (5 to 10 d) SW winds and eastward currents. In 2003, colonisation peaked at spring tide only when winds were not from SW and currents were not flowing eastwards. In 2005, colonisation rates peaked mainly at, or 1 to $3 \mathrm{~d}$ after, spring tide; periods of low colonisation were short, except at the end of the settlement season. According to an existing 2-step model and to local movement of megalopae, colonisation patterns in the intertidal may reflect transport processes: (1) settlement rates on Helgoland are primarily affected by wind-driven currents: SW winds transport larvae out of Helgoland waters, leading to low settlement rates, while other wind regimes transport them towards Helgoland. In the absence of strong SW winds, peaks of settlement at or after spring tide suggest (2) selective tidal stream transport or some form of tidally mediated flow. The absence of SW winds leads to a higher influence of local movement of megalopae, as the number of larvae reaching the benthic habitat is high. In consequence, colonisation of natural substratum may reflect larval transport processes and local movement of larvae in C. maenas and other invertebrates with mobile benthic stages.
\end{abstract}

KEY WORDS: Settlement · Recruitment - Megalopae $\cdot$ Larval transport $\cdot$ Postsettlement movements · North Sea Resale or republication not permitted without written consent of the publisher

\section{INTRODUCTION}

One of the central objectives of ecology is to understand the temporal and spatial patterns of organism abundance. In marine benthic species, a better understanding of such patterns is achieved if studies integrate different phases of their life cycles (Bhaud 1998, Connolly \& Roughgarden 2003, Giménez 2004).
In sessile benthic species, benthic and pelagic processes/factors usually affect benthic organisms at different spatial scales. Benthic processes, e.g. interactions between larvae and resident species (Osman et al. 1989, Jenkins et al. 1999) or benthic predation and competition among juveniles/adults, occur at spatial scales of metres (Roughgarden et al. 1988). Pelagic processes, such as those influencing larval supply, 
affect settlement, recruitment or other population processes (Hawkins \& Hartnoll 1982, Gaines \& Roughgarden 1985, Connolly \& Roughgarden 2003).

The situation differs for species with mobile benthic stages, such as crabs. While transport processes affect the arrival of larvae in coastal waters (Forward \& Tankersley 2001, Queiroga \& Blanton 2004), mobility of settling stages complicates the definition of settlement. For instance, in the shore crab Carcinus maenas, settlement does not seem to be an irreversible process: the degree of development seems to determine whether megalopae settle definitively or emigrate (Moksnes et al. 2003). Thus, at small scales, the distribution patterns of early life stages of mobile crustaceans are determined by the behaviour of megalopae (Hedvall et al. 1998, Moksnes et al. 2003).

In coastal species, regardless of whether these have mobile or sessile benthic stages, transport of larvae from the pelagic to the benthic habitat is seen as a 2-step process consisting of (1) onshore transport towards the coastal zone by (e.g.) wind-driven currents (Wing et al. 2003, Queiroga et al. 2006), and (2) transport to the benthic habitat as a consequence of interactions between shoreline configuration and nearshore circulation (Pineda 1999, Shanks et al. 2003). For mobile species, transport processes may explain patterns of spatial distribution at fairly large spatial scales. However, it is not clear whether or not temporal patterns of settlement reflect pre-settlement processes.

We studied the temporal variability in colonisation of megalopae of the shore crab Carcinus maenas. Our main objective was to determine if physical processes responsible for the transport of larvae affected their rate of settlement. All information about the role of physical processes on settlement rates and larval supply of shore crab are from studies within estuaries. For instance, on the Portuguese coast, larval supply to estuaries has been related to alongshore winds and tidal currents (Queiroga \& Blanton 2004, Paula et al. 2006, Queiroga et al. 2006). In the present study, we evaluated settlement on an open coast, in the intertidal zone of Helgoland (German Bight, North Sea, see Fig. 1). The settlement season of $C$. maenas varies regionally; in the North Sea it occurs between June and November (Scherer \& Reise 1981, Thiel \& Dernedde 1994). Both the Portuguese coast and the German Bight are mesotidal systems, but the latter is much shallower than the former.

In Portuguese estuaries, the colonisation rate of artificial substrata was uncoupled from larval supply (Paula et al. 2006, Queiroga et al. 2006). According to Paula et al. (2006), collectors based on artificial substratum strongly interfere with the surrounding natural substratum, affecting the interpretation of results on settlement rates. However, in our study we estimated

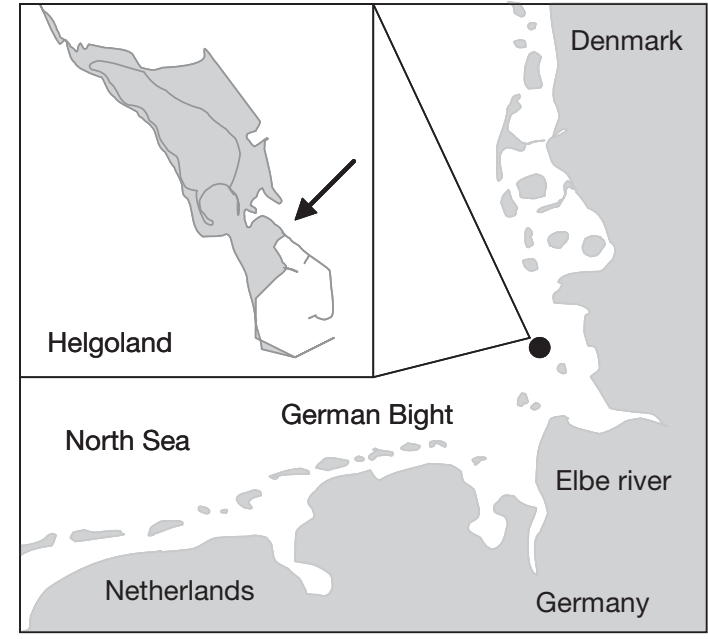

Fig. 1. Location of sampling site (arrow) off Helgoland, North Sea, German Bight (5410' 67.0" N, $7^{\circ} 53^{\prime} 54.3^{\prime \prime}$ E)

settlement on natural substratum while avoiding any interference in the evaluation of associations between settlement and physical processes related to larval transport. Our data suggest that there is indeed a coupling between larval supply and colonisation rate.

\section{MATERIALS AND METHODS}

Study site and data collection. The study site, off the island of Helgoland, North Sea, German Bight (Fig. 1), is a shallow semidiurnal mesotidal system. Colonisation was estimated in an intertidal sector characterised by boulders and coarse sediments (mainly gravel and cobble). At this site Carcinus maenas juveniles reach densities of about 300 to 600 ind. $\mathrm{m}^{-2}$ in gravel-cobble sediment (L. Giménez unpubl. data).

Colonisation rate was estimated using 3 replicate traps deployed every day for 24 to $26 \mathrm{~h}$, in the intertidal at diurnal low tide. The traps were randomly placed each day in a different place, between mean high water and mean low water; distance among traps was usually in the order of tens of metres. Each trap consisted of a PVC ring of $4 \mathrm{~cm}$ height and $314 \mathrm{~cm}^{2}$ surface area with a nylon mesh bottom of $500 \mu \mathrm{m}$. The traps were filled with natural defaunated sediment consisting of coarse gravel and cobble; traps were buried in order to avoid edge effects on bottom currents. Recovered traps were immediately taken to the laboratory where megalopae were immediately identified and counted.

Wind data were kindly provided by the German Weather Service (Deutscher Wetter Dienst, DWD) station on Helgoland as wind direction (32-sector Rosette) and wind force (Beaufort scale converted to $\mathrm{m} \mathrm{s}^{-1}$, whereby 
Bft $1=0.3$ to $1.5 \mathrm{~m} \mathrm{~s}^{-1}, 2=1.6$ to $3.3 \mathrm{~m} \mathrm{~s}^{-1}, 3=3.4$ to $5.4 \mathrm{~m}$ $\mathrm{s}^{-1}, 4=5.5$ to $7.9 \mathrm{~m} \mathrm{~s}^{-1}, 5=8.0$ to $10.7 \mathrm{~m} \mathrm{~s}^{-1}, 6=10.8$ to $13.8 \mathrm{~m} \mathrm{~s}^{-1}, 7=13.9$ to $17.1 \mathrm{~m} \mathrm{~s}^{-1}$, and $8=17.2$ to $20.7 \mathrm{~m}$ $\mathrm{s}^{-1}$ : World Meteorological Organization 1970). The N-S and $\mathrm{W}-\mathrm{E}$ components were regarded as positive when the wind was from the north or east, respectively.

Daily residual surface currents (0 to $8 \mathrm{~m}$ ), predicted from an operational circulation model developed by Federal Maritime and Hydrographic Agency for the

(a)

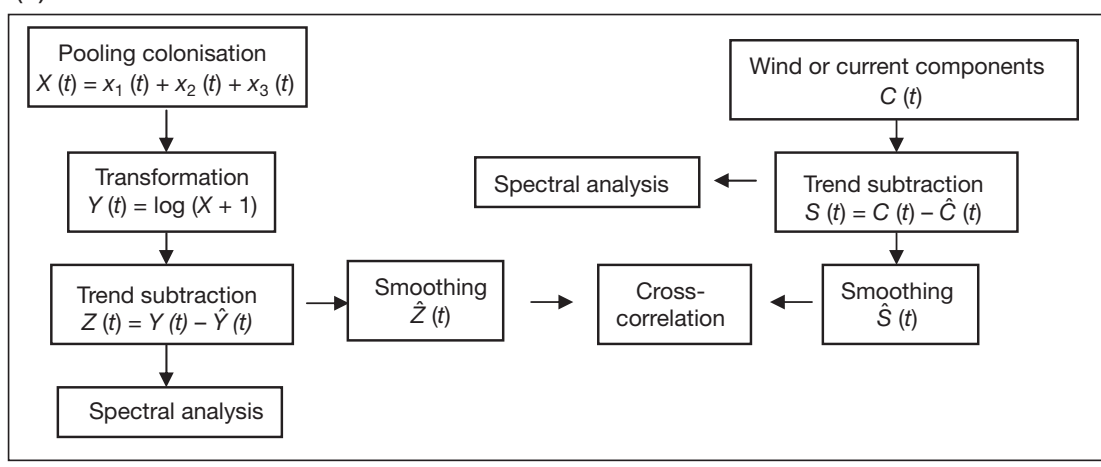

(b)
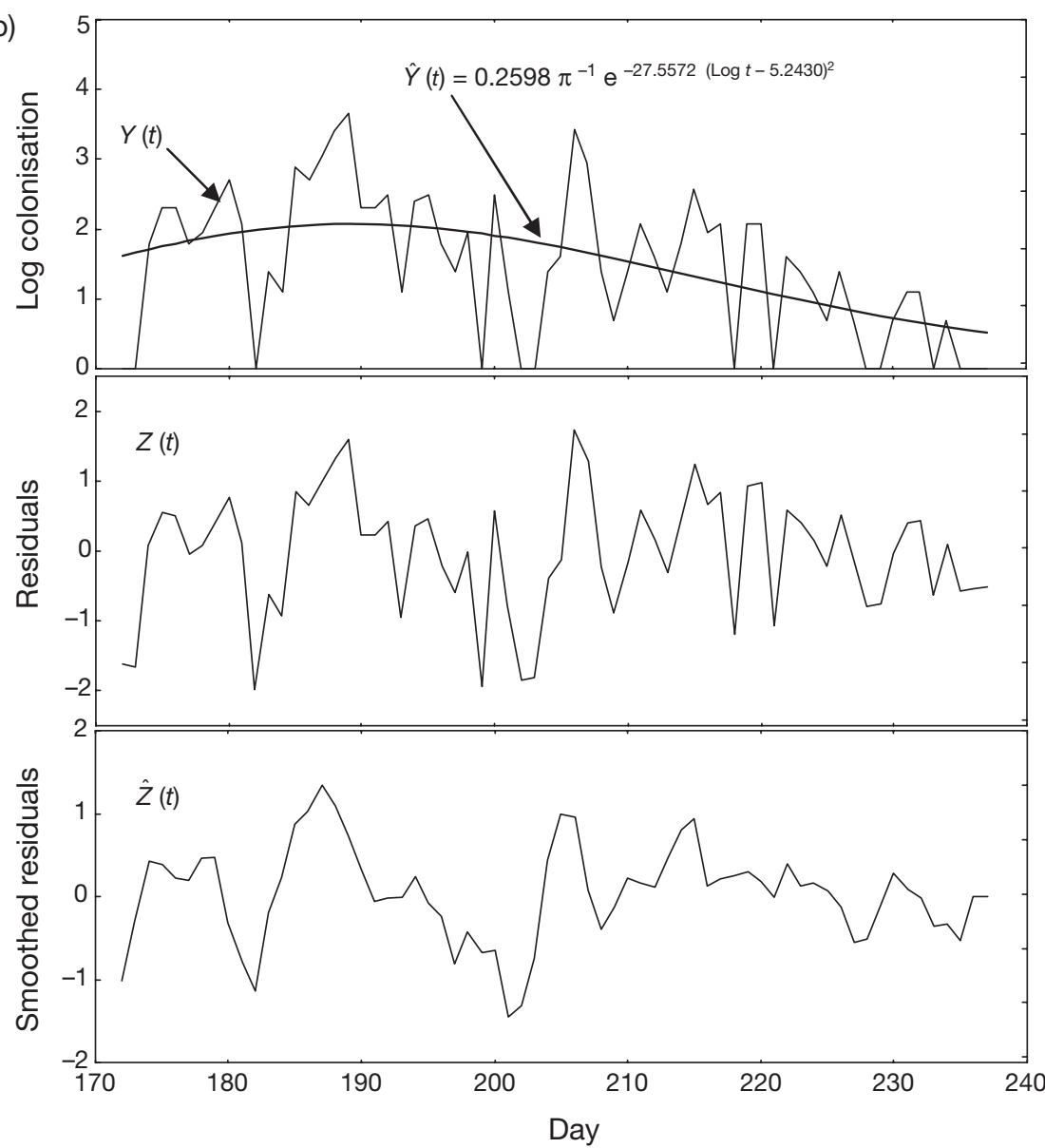

Fig. 2. Procedure for time series analysis. (a) Flow diagram showing data transformation for spectral analysis and cross-correlation; (b) example of data transformation for colonisation by Carcinus maenas megalopae in 2005 (data from Fig. 6)
German Bight (Dick et al. 2001), were used to explore potential effects of current patterns on colonisation of megalopae. The model simulates tidal-, density- and wind-driven motion. Based on meteorological forecasts supplied by the DWD, the hydrodynamical model predicts currents in a nested grid system. The model had been previously validated in the North Sea with good agreement between data and predictions (Klein \& Dick 1999, Dick et al. 2001), and has been successfully used to predict and combat marine pollution (e.g. Dahlmann \& MüllerNavarra 1997). Current components were calculated from predicted surface current fields in the German Bight with $1.8 \mathrm{~km}$ grid spacing. The data covering $50 \mathrm{~km}$ around Helgoland were coded in an 8-sector rosette. Current components are positive if currents are moving eastwards or northwards.

Data analysis. Time series analysis followed the protocol shown in Fig. 2a (after Chatfield 2004) using Statistica ${ }^{\circledR}$. For abundance data, colonisation rate of all collectors were pooled each day. Visual inspection of the time series showed trends and considerable variability, which increased with increasing abundance. Therefore, colonisation data were $\log (x+1)$-transformed, the trend removed, and the data smoothed by a 3 points moving-average. The function used for trend extraction depended on the year: for 2003 and 2004 data showed either an increasing or a decreasing trend, so a linear function was used; in 2005 data showed a humped pattern, and the trend was extracted using a log-normal function adjusted by non-linear regression (Fig. 2b).

Spectral analysis of the de-trended time series of abundance was used to explore temporal patterns of variation. Relationships between abundance, wind and predicted currents were explored using cross-correlation analysis after smoothing all series. Potential relationships between abundance and tidal cycles were also explored with cross-correlation analysis, using the days since spring tide as variable. All cross-correlations were done by lagging the predictor 

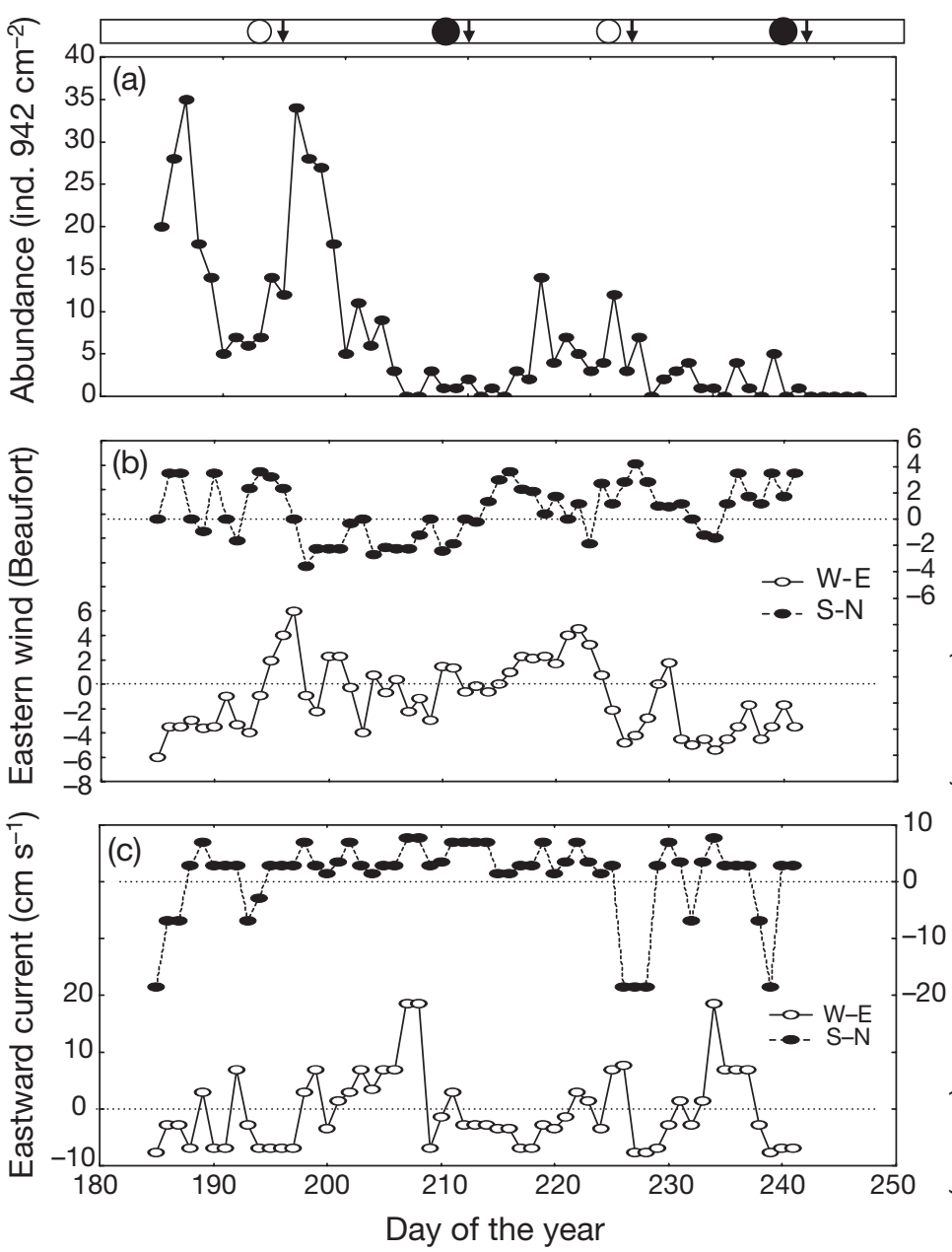

Fig. 3. Time series for year 2003. (a) Colonisation of traps by Carcinus maenas megalopae; (b) wind direction; (c) predicted residual currents. Bar along top abscissa shows times of spring tides (arrows), and new (๑) and full (O) moons

variable (e.g. current component) whereby correlation at a negative lag $=\lambda$ indicates that the response variable at Time $t$ was predicted by the predictor variable at Time $t-\lambda$.

\section{RESULTS}

\section{Temporal patterns}

The settlement season extended from the end of June to the end of August. Colonisation varied within and among years; in some cases there were peaks followed by periods of low or no colonisation. In 2003, there were 2 main periods of colonisation (Fig. 3a) separated by a period with very few larvae (density $<5 \mathrm{~d}^{-1}$ ): the first colonisation period occurred between Days 184 and 203, with moderate to high rates of colonisation (5 to 40 ind. $\mathrm{d}^{-1}$ ) and was characterised by 2 peaks. The second period (Days 214 to 224) showed moderate colonisation rates (5 to 15 ind. $\mathrm{d}^{-1}$ ). Winds from the NW dominated the first colonisation period (Fig. 3b), with wind shifting to the SE and then to the SW 2 to $3 \mathrm{~d}$ before the end of this period and remaining in that quadrant until the end of July. In August, wind was variable, although it was chiefly from the NE. Residual currents towards the NW or SW were predicted for the first colonisation period (Fig. 3c), but they shifted towards the NE as wind directions rotated; during the next 11 to $12 \mathrm{~d}$ predicted currents were towards the NE. In August, currents shifted again towards the NW a few days before the second period of larval colonisation. Spectral analysis of the 2003 data (Fig. 4a) revealed a major peak every $26 \mathrm{~d}$ and smaller peaks every 4 to $5 \mathrm{~d}$ and $16 \mathrm{~d}$.

In 2004 (Fig. 5a), colonisation rate was initially low (5 to 6 ind. $\mathrm{d}^{-1}$ : Days 173 to 190 ), but increased to moderate levels thereafter. Due to technical problems it was not possible to continue the time series during August.
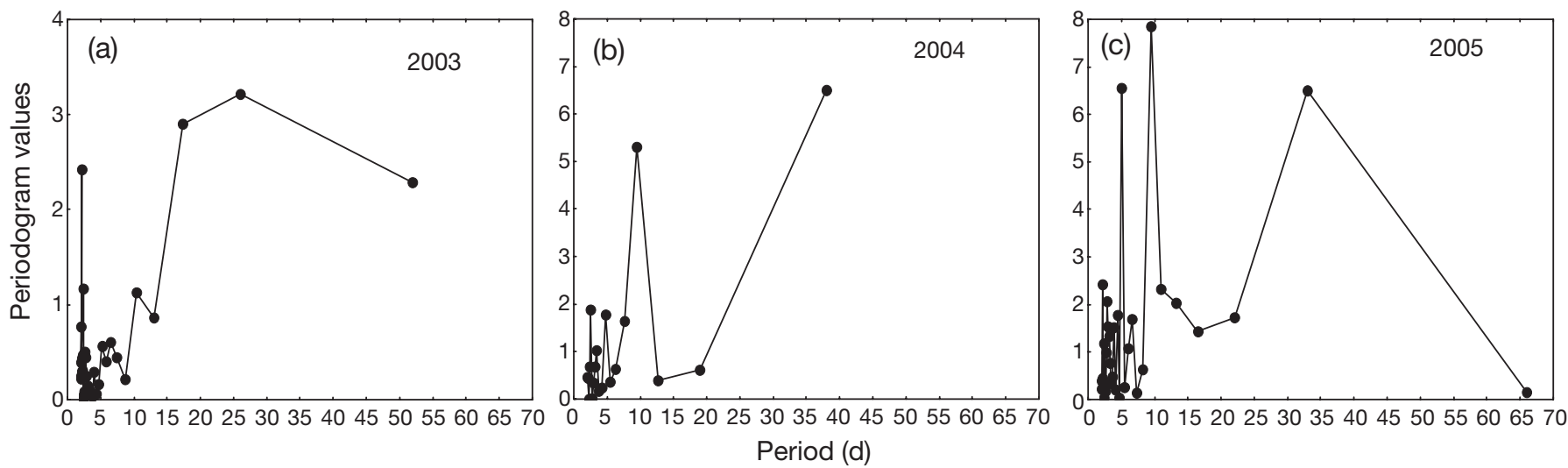

Fig. 4. Carcinus maenas. Spectral analysis of time series of colonisation rate by megalopae in 3 consecutive years 
The period of low colonisation rate was dominated by strong SW winds; predicted residual currents were towards the NE, with high speeds. This situation changed a few days before the increase in colonisation, with winds relaxing and shifting between SE and NW, and predicted residual currents tending to move westwards. For 2004 (Fig. 4b), spectral analysis of colonisation showed peaks at periods of 10 and $38 \mathrm{~d}$, while short-term variation $(<5 \mathrm{~d})$ was not important.

In 2005, the colonisation rate was mostly moderate, with several peaks of high density (>15 ind. $\mathrm{d}^{-1}$ ) and with only short periods ( 1 to $3 \mathrm{~d}$ ) of low density (Fig. 6a); the only long period of low density was at the end of the settlement season (after Day 220). Winds showed low variations in magnitude: they were mostly from the NW, with short periods $(<4$ d) from the SE and NE. Predicted residual currents also showed low variation in magnitude; they flowed towards the NW and SW during most of the settlement season, with short periods in a NE or SE direction. Spectral analysis of the 2005 data showed peaks at periods of 5,10 and $32 \mathrm{~d}$ (Fig. 4c).

\section{DISCUSSION}

Using correlative analysis, this study evaluated the importance of transport processes on the colonisation rate of natural substrata by megalopae of the shore crab Carcinus maenas. In the absence of a manipulative experimental design, causality may be tested by repeating observations in space and time. For this reason, a 3 yr data set was used, thus obtaining more robust conclusions. The data showed variability among and within years, with patterns observed in one year not necessarily being repeated in the following year. For instance, July of 2003 and 2005 was characterised by high colonisation rates, while in 2004, this month had lower rates. Within years, 2003 and 2004 were characterised by periods of 5 to $10 \mathrm{~d}$ of very low colonisation, while in 2005 low colonisation occurred only at the end of the settlement season.

The observed variability in the colonisation rate of megalopae may be due to a combination of presettlement processes (e.g. larval transport affecting larval supply) and by larval movements, development and mortality in the intertidal. In Carcinus maenas, lar-

\section{Relationships among variables}

In 2003, colonisation rate was significantly correlated with tidal cycle, suggesting maximal colonisation 3 to $4 \mathrm{~d}$ after spring tide (Table 1). Correlations were also statistically significant after northern winds (lag $=0$ to 5 d), suggesting that maximum colonisation followed north winds and minimum colonisation followed south winds. Significant correlations between colonisation and predicted residual currents suggested that minimum colonisation followed after eastwards currents $(\operatorname{lag}=0$ to $5 \mathrm{~d})$.

In 2004, colonisation rate was not significantly correlated with tidal cycle (Table 1). Correlations with wind direction were significant, suggesting maximum colonisation after N-NE winds and minimum colonisation after SW winds. Correlations with predicted residual currents suggested that minimum abundance followed after N-E currents, with a lag of $4 \mathrm{~d}$.

In 2005, relationships between colonisation rates and tidal cycle were statistically significant, suggesting maximum values 1 to $3 \mathrm{~d}$ after spring tide (Table 1). Correlations with wind were negative, suggesting minima after north winds (lag $=5 \mathrm{~d}$ ); correlations with residual currents were positive, suggesting maxima after current relaxation or slightly eastward currents.
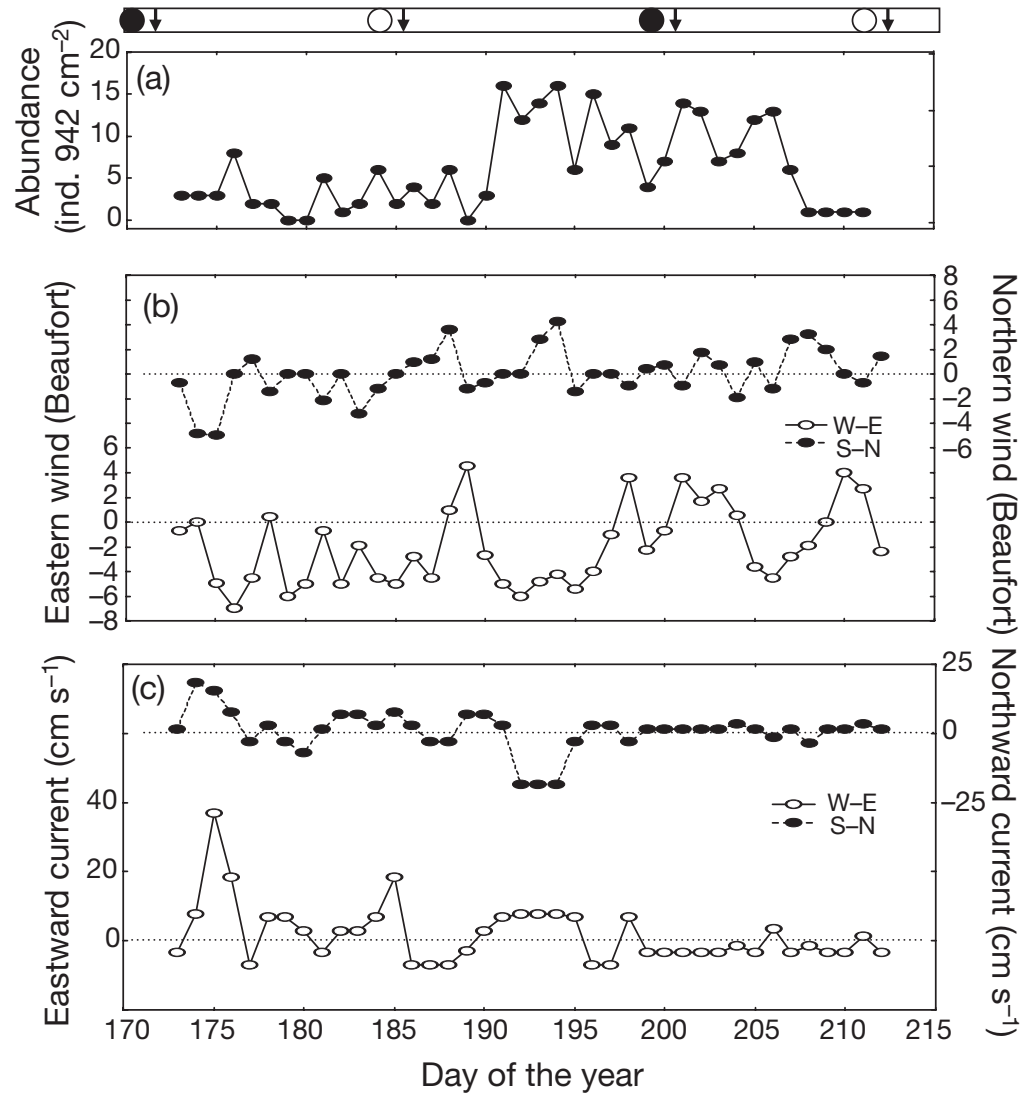

Fig. 5. Time series for year 2004. (a) Colonisation of traps by Carcinus maenas megalopae; (b) wind direction; (c) predicted residual currents. Further details as in Fig. 3 

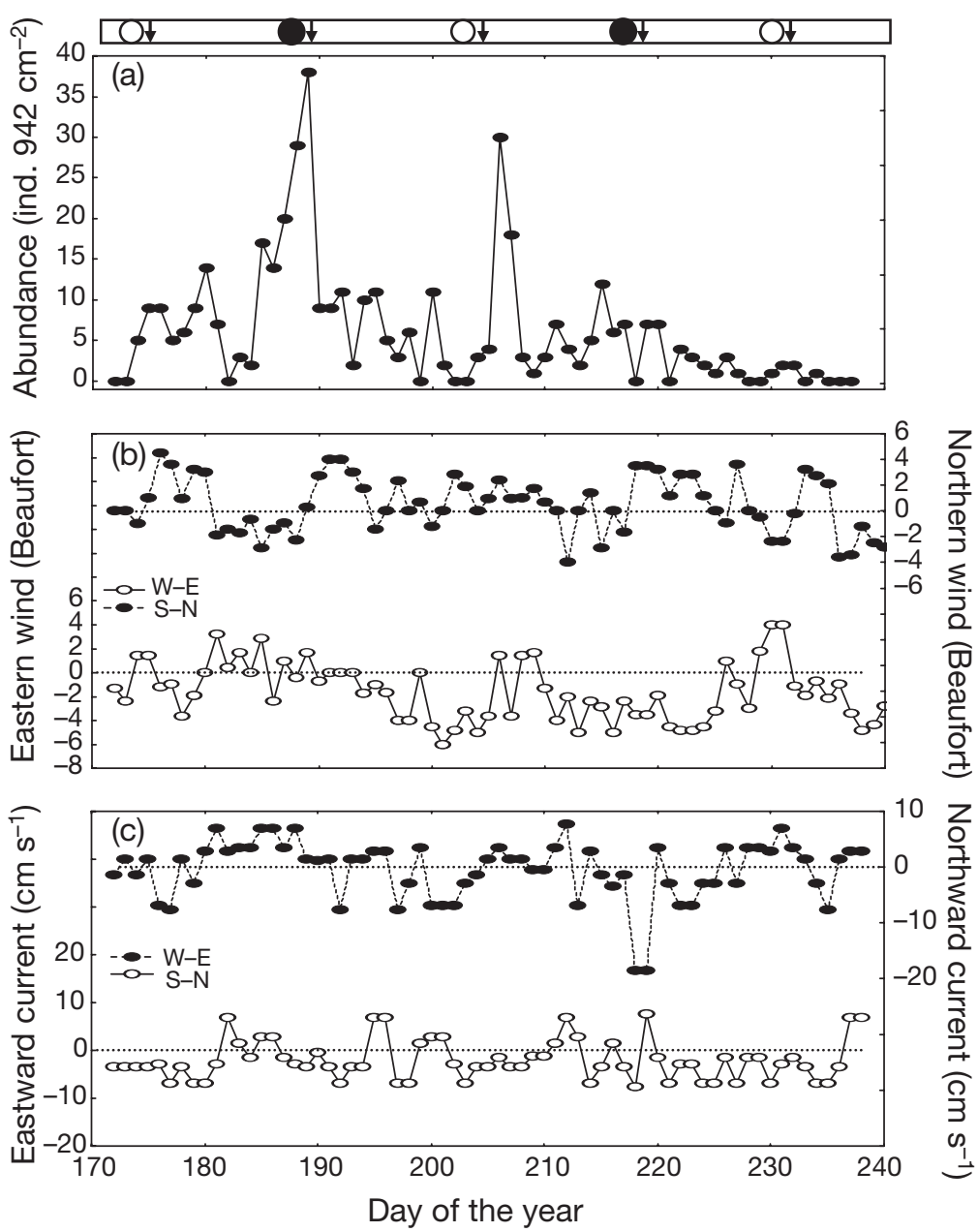

Fig. 6. Time series for year 2005. (a) Colonisation of traps by Carcinus maenas megalopae; (b) wind direction; (c) predicted residual currents. Further details as in Fig. 3

val supply has been related to tidal and wind-driven currents (Queiroga et. al. 2006). We used a model for predicting surface (0 to $8 \mathrm{~m}$ depth) currents to assess the importance of water circulation; however, distribution of megalopae may also be affected by circulation in deeper layers. If a pycnocline were present in our study area we would need to consider movements below the pycnocline. However, in the German Bight the summer thermocline forms mostly at depths $>40 \mathrm{~m}$, well offshore from Helgoland, and haloclines are formed near the mouths of the estuaries. During most of the year, Helgoland lies outside these areas (Krause et al. 1986, Luyten et al. 2003, Loewe et al. 2005).

The fact that $>90 \%$ of individuals colonising the traps metamorphosed to juveniles after $<6$ d (L. Giménez unpubl. data) suggests that we captured only larvae at an advanced stage of development. Although this could have increased the noise in our results related to supply, these larvae are those most likely to remain in the intertidal. Larval movement during set- tlement was studied only on the Swedish coast, where emigration of megalopae from the benthos occurs mainly at dusk and at night; emigration is higher if megalopae need $>2 \mathrm{~d}$ to reach metamorphosis (Moksnes et al. 2003). Juvenile blue crabs Callinectes sapidus respond positively to currents and turbulence by planktonic dispersal (Blackmon \& Eggleston 2001). If megalopae settling on Helgoland also respond to these factors, then the patterns in the present study may have resulted from movement within the nursery habitat. However, such movement cannot explain all the patterns observed, since: (1) while the most important colonisation peaks were separated by periods $\geq 10 \mathrm{~d}$, most megalopae (>90\%) transferred to the laboratory took $\leq 6 \mathrm{~d}$ to reach the first juvenile stage. Therefore, each colonisation peak should represent a new cohort of megalopae. (2) We recovered and deployed collectors during daylight hours to avoid variability due to twilight or nocturnal emigration. (3) Strong eastward currents produced as much turbulence in the intertidal westward currents (L. Giménez pers. obs.); however, colonisation of traps was consistently low during periods of eastward currents. Movements within the settlement habitat could explain a considerable proportion of variability at a scale of $\leq 5 \mathrm{~d}$ : variation at this scale was recorded in 2003 and 2005 during periods of high colonisation.

The present data suggest that colonisation rates were indeed affected by transport processes through changes in larval supply. In 2003 and 2004, colonisation rate was negatively correlated with SW winds and eastward currents, suggesting that megalopae were transported from the east of Helgoland, perhaps from near the Wadden Sea or from the mouth of the Elbe River, where plume fronts are present (Krause et al. 1986, Otto et al. 1990). In agreement with our hypothesis, larvae of Carcinus maenas concentrate in coastal areas of the North Sea (Lindley 1987). Steiff (1989) found that C. maenas was common in the inner German Bight, with a distribution limit near Helgoland. In the German Bight, SW winds lead to cyclonic water transport (Dippner 1998, Loewe et al. 2005, and Fig. 7a) and to a northwards and onshore displacement of the plumes from rivers (Dippner 1993, Luyten et al. 2003). Other wind conditions could move coastal waters towards Helgoland (Fig. 7b). 
Table 1. Carcinus maenas. Results of cross-correlation analysis evaluating potential relationships between colonisation rate by megalopae and physical variables. Only lags $(\lambda$ in days) between -5 and $0 \mathrm{~d}$ and correlations (r) larger than the expected $95 \%$ confidence interval for white noise are shown. Negative lags indicate that the colonisation at Time $t$ is explained by the physical variable at Time $t-\lambda$. Positive correlations indicate increasing abundance at spring tide, with winds from $\mathrm{N}$ or $\mathrm{E}$, and with eastward or northward currents. ns: non-significant correlation

\begin{tabular}{|c|c|c|c|c|c|c|}
\hline \multirow{2}{*}{$\begin{array}{l}\text { Forcing } \\
\text { factor }\end{array}$} & \multicolumn{2}{|c|}{2003} & \multicolumn{2}{|c|}{2004} & \multicolumn{2}{|c|}{2005} \\
\hline & $\lambda$ & $\mathrm{r}$ & $\lambda$ & $\mathrm{r}$ & $\lambda$ & $\mathrm{r}$ \\
\hline Tide & $\begin{array}{l}-3 \\
-4 \\
-5\end{array}$ & $\begin{array}{l}+0.32 \\
+0.34 \\
+0.31\end{array}$ & & ns & $\begin{array}{l}-1 \\
-2 \\
-3\end{array}$ & $\begin{array}{l}+0.28 \\
+0.31 \\
+0.27\end{array}$ \\
\hline $\begin{array}{l}\text { Eastern } \\
\text { wind }\end{array}$ & & $\mathrm{ns}$ & -1 & +0.18 & & ns \\
\hline $\begin{array}{l}\text { Northern } \\
\text { wind }\end{array}$ & $\begin{array}{r}0 \\
-1 \\
-2 \\
-3 \\
-4 \\
-5\end{array}$ & $\begin{array}{l}+0.35 \\
+0.51 \\
+0.49 \\
+0.47 \\
+0.38 \\
+0.39\end{array}$ & $\begin{array}{l}-4 \\
-5\end{array}$ & $\begin{array}{l}+0.45 \\
+0.55\end{array}$ & -5 & -0.31 \\
\hline $\begin{array}{l}\text { Eastward } \\
\text { current }\end{array}$ & $\begin{array}{r}0 \\
-1 \\
-2 \\
-3 \\
-4 \\
-5\end{array}$ & $\begin{array}{l}-0.40 \\
-0.41 \\
-0.47 \\
-0.48 \\
-0.52 \\
-0.51\end{array}$ & $\begin{array}{l}-4 \\
-5\end{array}$ & $\begin{array}{l}-0.41 \\
-0.38\end{array}$ & $\begin{array}{l}-4 \\
-5\end{array}$ & $\begin{array}{l}+0.32 \\
+0.39\end{array}$ \\
\hline $\begin{array}{l}\text { Northward } \\
\text { current }\end{array}$ & & $\mathrm{ns}$ & $\begin{array}{l}-4 \\
-5\end{array}$ & $\begin{array}{l}-0.44 \\
-0.41\end{array}$ & & $\mathrm{~ns}$ \\
\hline
\end{tabular}

In 2003, colonisation rate was positively correlated with spring-neap tidal cycles, peaking at or after spring tide, except at times of strong SW winds. In 2004, the correlation was not statistically significant: during one of the 2 spring tides sampled, strong SW winds and eastward currents may have overridden the effect of the tides. Thus, the data from these years suggest that (1) strong and persistent SW winds and eastward currents preclude colonisation of the intertidal at Helgoland (under other wind regimes the colonisation rate was moderate to high); (2) there may be a tidal effect if SW winds and eastward currents are not strong and persistent. In 2005, colonisation rates tended to be moderate to high; concurrently, SW winds and predicted eastward currents were not strong and never persisted longer than 3 to $4 \mathrm{~d}$. In this year there were colonisation peaks around spring tide. Although spectral analysis suggested that peaks of colonisation occurred every $10 \mathrm{~d}$, correlations of colonisation with the tidal cycle support the idea that when SW winds are not persistent, a tidal effect is present. In 2005, the correlations between colonisation rates and wind direction or predicted residual currents were opposite to those in the 2 previous years. However, there were a
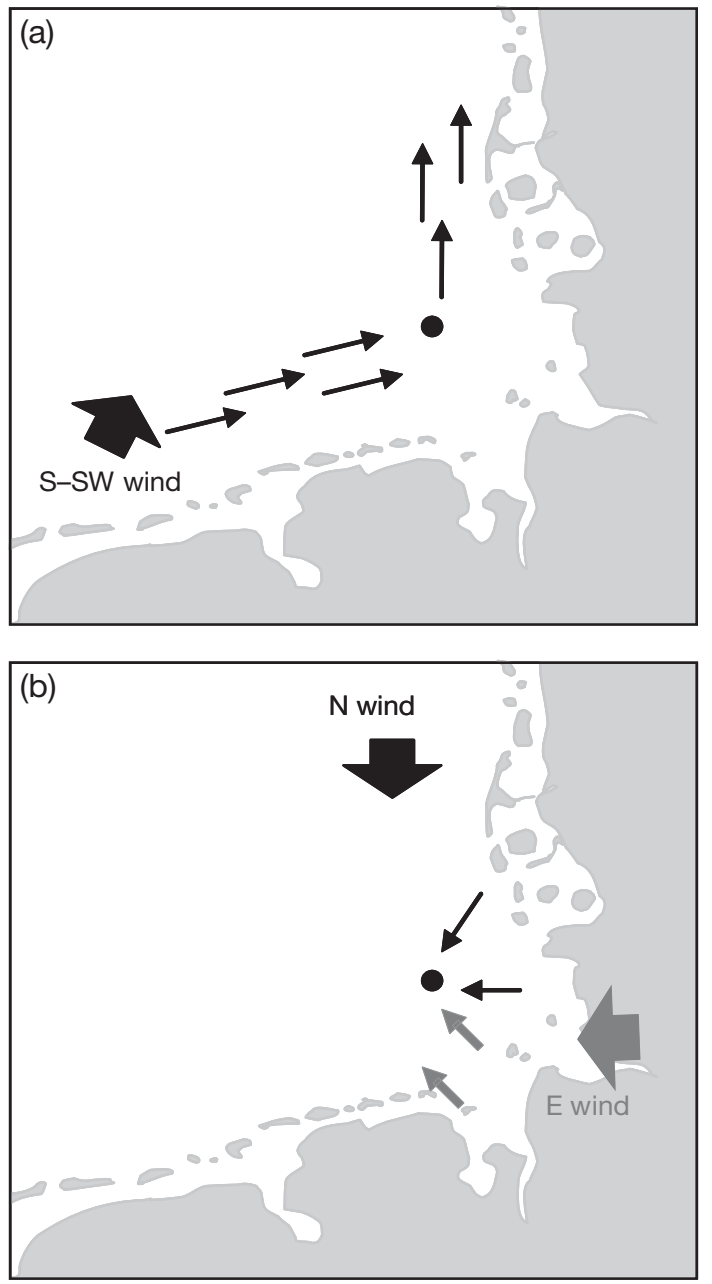

Fig. 7. Proximate residual circulation patterns around Helgoland for (a) a southwesterly wind and (b) winds from other directions

number of differences between 2005 and the previous years: (1) In 2005, periods of low larval abundance ( $\leq 5$ individuals) were very short, with the expected exception of the end of the settlement season. This was not the case in 2003 and 2004, when long periods (>5 d) of low abundance occurred. (2) The ranges in wind force (northerly component) and eastward current speed were narrower in 2005 than in 2003 and 2004. This was especially clear for the eastward current component, which never rose beyond $+10 \mathrm{~cm} \mathrm{~s}^{-1}$ and was greater than $+5 \mathrm{~cm} \mathrm{~s}^{-1}$ on only 5 occasions, during the whole settlement period. In contrast, in 2003 and 2004 the eastward component was $>5 \mathrm{~cm} \mathrm{~s}^{-1}$ for periods longer than $5 \mathrm{~d}$, reaching $>10 \mathrm{~cm} \mathrm{~s}^{-1}$ within these periods, which were periods with low colonisation rates. (3) With regard to wind direction, southerly winds in 2005 were from the SE (e.g. on Days 180 to 185, Fig. 6), not from the SW as in 2003 and 2004. In 
2004, the year with higher variations in winds and predicted current, we found a significant negative correlation with northward currents and a positive correlation with the easterly winds. Therefore, correlations depend on the range in variation and strong SW winds, and an anticlockwise circulation pattern reduces colonisation. (4) Spectral analysis of the northerly wind and eastward current of 2005 revealed a peak at a period of nearly $15 \mathrm{~d}$ (data not shown). Thus, both varied at approximately the same frequency as the springneap cycle. Colonisation peaks occurred after relaxation of the predicted eastward residual currents (Days 200 to 210, Fig. 6). Either these correlations arose from coincidental variation between tidal cycles and winds, or they indicate that colonisation increases after current relaxation. It is thus clear that strong and persistent ( $>5 \mathrm{~d}$ long) periods of SW winds and eastward currents lead to low colonisation rates, while under other wind or current conditions, e.g. current relaxation or westward currents, colonisation apparently varies as a function of tide.

Our hypothesis is consistent with a 2-step model of larval supply formulated for coastal marine species in general (see Miller \& Shanks 2004 for discussion) and supported by Carcinus maenas data from Portugal (Queiroga et al. 2006). In addition, the influence of local movements of megalopae on colonisation patterns may be contingent on the overall number of larvae reaching the benthic habitats.

As an initial step in larval transport, wind-driven currents are thought to transport larvae across the continental shelf towards the coast (Shanks 1995, Wing et al. 2003); in Portugal, the supply of Carcinus maenas megalopae to estuaries may be related to upwelling fronts reaching the coast after wind relaxation (Almeida \& Queiroga 2003, Queiroga et. al. 2006). In the North Sea, variations in westward wind-driven transport may move larvae away or towards Helgoland.

Near the coast in mesotidal systems, selective tidal stream transport (STST, Forward \& Tankersley 2001) or some form of tidally mediated water flow may transport larvae shorewards in pulses of about $2 \mathrm{wk}$, at or a few days after spring tides; this may be the second step in transport, as observed for Carcinus maenas in Portugal (Queiroga et al. 2006). This second step is contingent on the first step, since $2 \mathrm{wk}$ pulses were observed in the absence of strong SW winds or eastward currents. In the estuaries along the Portuguese coasts, zero time lags suggest STST, although the influence of internal waves cannot be disregarded (Queiroga et al. 2006). Following Miller \& Shanks (2004) and Queiroga et al. (2006), the time lags of 1 to $5 \mathrm{~d}$ for Helgoland suggest a combined effect of STST and internal waves on larval colonisation. The STST has been invoked for megalopae invading estuaries: here cues associated with estuarine water (e.g. low salinity) may entrain the appropriate swimming behaviour of megalopae. Data for coastal zones are sparse (Necora puber: Lee et al. 2005; C. maenas in mesotidal coastal zone of Wales: Zeng \& Naylor 1996, Queiroga 1998), but those that are available for $C$. maenas show that larvae are more abundant near the surface water at flood tide, especially at night. This pattern would predict maximum larval supply to the intertidal of Helgoland during spring tides, since at this time at least 1 high tide occurs at night. According to Zeng \& Naylor (1996) this pattern is not endogenous, but due to some exogenous factor, perhaps related to the intertidal proximity (e.g. turbulence).

Tidally mediated flow may be related to internal waves through at least 3 different transport mechanisms, involving shoreward movements of (1) convergence zones, (2) upwelling fronts, and (3) cold bores (Pineda 1999, Shanks 2006). River plumes, such as those of the Elbe and Wesser, may be a source of largeamplitude internal waves (Nash \& Moum 2005); however, according to W. Alpers (www.internalwaveatlas.com) internal waves are present only sporadically in the North Sea, mainly in the summer months. An analysis of density fronts and residual circulation of the German Bight, under minimal wind effects (Luyten et al. 2003) suggest that a southward flow can be expected at neap tide, while a northward flow can be expected at spring tide. This pattern should result in peaks of Carcinus maenas settlement on Helgoland around spring tides. In summary, several mechanisms may explain the abundance peaks around spring tides; however, the fact that spectral analysis shows a periodicity of $10 \mathrm{~d}$, instead of 14 to $15 \mathrm{~d}$, suggests that further studies are necessary to elucidate the tidal mechanisms operating in the German Bight.

Finally, the influence of emigration-immigration cycles of megalopae on colonisation rates should also be contingent on the absence of strong SW winds. This was the case in the 2005 and part of the 2003 settlement period, with marked short-period (ca. 5 d) variability in colonisation rate. SW winds or eastward currents should lead to low settlement rates and a low number of megalopae colonising the sediment.

In summary, variability in intertidal colonisation by megalopae of the shore crab Carcinus maenas in the North Sea may be related to wind-driven current and tidal conditions. Colonisation is low under strong and persistent eastward currents, whereas under other conditions (westward currents or during relaxation events), colonisation may be high and related to spingneap tidal cycles. Future work should elucidate the mechanisms of larval transport in the North Sea and relationships between larval supply, colonisation and juvenile recruitment in the intertidal. 
Acknowledgements. This work is part of the postdoctoral research of L.G., financed by the Alexander von Humboldt Stiftung, Germany; L.G. thanks Dr. K. Anger for receiving him at his laboratory and for his invaluable support. Thanks to the Deutscher Wetter Dienst, in particular Mr. H. Schmack, for providing and answering questions on wind data. This manuscript was greatly improved by comments from Dr. H. Queiroga, the Editor, and 4 anonymous reviewers.

\section{LITERATURE CITED}

Almeida M, Queiroga H (2003) Physical forcing of onshore transport of crab megalopae in the northern Portuguese upwelling system. Estuar Coast Shelf Sci 57:1091-1102

Bhaud M (1998) Two contradictory elements determine invertebrate recruitment: dispersion of larvae and spatial restrictions on adults. Oceanol Acta 23:409-422

Blackmon D, Eggleston D (2001) Factors influencing planktonic, post-settlement dispersal of early juvenile blue crabs (Callinectes sapidus Rathbun). J Exp Mar Biol Ecol 257:183-203

Chatfield C (2004) The analysis of time series. Chapman \& Hall, London

Connolly S, Roughgarden J (2003) Theory of marine communities: competition, predation, and recruitment dependent interaction strength. Ecol Monogr 69:277-296

Dahlmann G, Müller-Navarra S (1997) The source of oil pollution on the East Frisian Islands in October 1989-an exemplary case. Dtsch Hydrogr Z 49:35-43

Dick S, Kleine E, Müller-Navarra S, Klein H, Komo H (2001) The operational circulation model of BSH (BSHcmod). Model description and validation. Ber Bundesamt Seeschifffahrt Hydrogr 29:48

Dippner J (1993) A frontal-resolving model for the German Bight. Cont Shelf Res 13:49-66

Dippner J (1998) Vorticity analysis of transient shallow water eddy fields at the river plume front of the River Elbe in the German Bight. J Mar Syst 14:117-133

Forward R, Tankersley R (2001) Selective tidal-stream transport of marine animals. Oceanogr Mar Biol Annu Rev 39: 305-353

Gaines S, Roughgarden J (1985) Larval settlement rate: a leading determinant of structure in an ecological community of the marine intertidal zone. Proc Natl Acad Sci USA 82:3707-3711

Giménez L (2004) Marine community ecology: importance of trait-mediated effects propagating through complex life cycles. Mar Ecol Prog Ser 283:303-310

Hawkins S, Hartnoll R (1982) Settlement patterns of Semibalanus balanoides (L.) in the Isle of Man (1977-1981). J Exp Mar Biol Ecol 62:271-283

Hedvall O, Moksnes P, Pihl L (1998) Active selection by megalopae and juvenile shore crabs Carcinus maenas: a laboratory study in an annular flume. Hydrobiologia 375/376:89-100

Jenkins S, Norton T, Hawkins S (1999) Settlement and postsettlement interactions between Semibalanus balanoides (L.) (Crustacea: Cirripedia) and three species of fucoid canopy algae. J Exp Mar Biol Ecol 236:49-67

Klein H, Dick S (1999) Currents at the German Bight lightship: a comparison between ADCP measurements and the BSH forecast model. Dtsch Hydrogr Z 51:465-475

Krause G, Budeus G, Gerdes D, Schaumann K, Hesse K (1986) Frontal systems in the German Bight and their physical and biological effects. In: Nihoul JCJ (ed) Marine interphases ecohydrodynamics. Elsevier, Amsterdam, p 119-140

Lee J, Coleman R, Jones M (2005) Vertical migration during tidal transport of megalopae of Necora puber in coastal shallow waters during daytime. Estuar Coast Shelf Sci 65: 396-404

Lindley J (1987) Continuous plankton records: the geographical distribution and seasonal cycles of decapod crustacean larvae and pelagic post-larvae in the north-eastern Atlantic Ocean and the North Sea, 1981-3. J Mar Biol Assoc UK 67:145-167

Loewe P, Schmolke S, Becker G, Brockmann U and 12 others (2005) Nordseezustand 2003. Ber Bundesamt Seeschifffahrt Hydrogr 38:1-203

Luyten P, Jones J, Proctor R (2003) A numerical study of the long- and short-term temperature variability and thermal circulation in the North Sea. J Phys Oceanogr 33:37-56

Miller J, Shanks A (2004) Ocean-estuary coupling in the Oregon upwelling region: abundance and transport of juvenile fish and of crab megalopae. Mar Ecol Prog Ser 271: $267-279$

Moksnes PO, Hedvall O, Reinwald T (2003) Settlement behavior in shore crabs Carcinus maenas: why do postlarvae emigrate from nursery habitats? Mar Ecol Prog Ser 250:215-230

Nash J, Moum J (2005) River plumes as a source of largeamplitude internal waves in the coastal ocean. Nature 437 : 400-403

Osman RW, Whitlatch RB, Zajac RN (1989) Effects of resident species on recruitment into a community: larval settlement versus post-settlement mortality in the oyster Crassostrea virginica. Mar Ecol Prog Ser 54:61-73

Otto L, Zimmerman J, Furnes G, Mork M, Saetre, R, Becker G (1990) Review of the physical oceanography of the North Sea. Neth J Sea Res 26:161-238

Paula J, Silva I, Francisco S, Flores A (2006) The use of artificial benthic collectors for assessment of spatial patterns of settlement of megalopae of Carcinus maenas (L.) (Brachyura: Portunidae) in the Lower Mira Estuary, Portugal. Hydrobiologia 557:69-77

Pineda J (1999) Circulation and larval distribution in internal tidal bore warm fronts. Limnol Oceanogr 44:1400-1414

Queiroga H (1998) Vertical migration and selective tidal stream transport in the megalopa of the crab Carcinus maenas. Hydrobiologia 375/376:137-149

Queiroga H, Blanton J (2004) Interactions between behaviour and physical forcing in the control of horizontal transport of decapod crustacean larvae. Adv Mar Biol 47:107-214

Queiroga H, Almeida MJ, Alpuim T, Flores AAH and 5 others (2006) Tide and wind control of megalopal supply to estuarine crab populations on the Portuguese west coast. Mar Ecol Prog Ser 307:21-36

Roughgarden J, Gaines S, Possingham H (1988) Recruitment dynamics in comlpex life cycles. Science 241:1460-2466

Scherer B, Reise K (1981) Significant predation on micro- and macrobenthos by the crab Carcinus maenas L. in the Wadden Sea. Kiel Meeresforsch Sonderh 5:490-500

Shanks A (1995) Mechanisms of cross-shelf dispersal of larval invertebrates and fish. In: McEdward L (ed) Ecology of marine invertebrate larvae. CRC Press, Boca Raton, FL, p 323-367

Shanks A (2006) Mechanisms of cross-shelf transport of crab megalopae inferred from a time series of daily abundance. Mar Biol 148:1383-1398

Shanks A, McCulloch A, Miller J (2003) Topographically generated fronts, very nearshore oceanography and the distribution of larval invertebrates and holoplankters. 
J Plankton Res 25:1251-1277

Steiff B (1989) Die Brachyuren-Larven (Crustacea: Decapoda) in der Deutschen Bucht: Vorkommen, Entwicklung und Verbreitung. Dissertation, University of Hamburg

Thiel M, Dernedde T (1994) Recruitment of shore crabs Carcinus maenas on tidal flats: mussel clamps as an important refuge for juveniles. Helgol Meeresunters 48: 321-332

Wing S, Botsford L, Morgan L, Diehl J, Lundquist C (2003) Inter-annual variability in larval supply to populations of

Editorial responsibility: Howard Browman (Associate Editorin-Chief), Storebø, Norway three invertebrate taxa in the northern California Current. Estuar Coast Shelf Sci 57:859-872

World Metereological Organization (1970) The Beaufort scale of wind force (Technical and operational aspects). Commission for Marine Meteorology, Report on Marine Science Affairs 3, Geneva, p 22

Zeng C, Naylor E (1996) Occurrence in coastal waters and endogenous tidal swimming rhythms of late megalopae of the shore crab Carcinus maenas: implications for onshore recruitment. Mar Ecol Prog Ser 136:69-79

Submitted: July 14, 2006; Accepted: October 10, 2006 Proofs received from author(s): May 3, 2007 